\title{
Evaluasi Karakter Hortikultura Galur Cabai Hias IPB di Kebun Percobaan Leuwikopo
}

\author{
Horticulture Trait Evaluation of IPB Ornamental Pepper Lines \\ in Leuwikopo Experimental Field \\ Alvianti Yaufa Desita ${ }^{1}$ Dewi Sukma $^{1^{*}}$, dan Muhammad Syukur $^{1}$ \\ Diterima 8 April 2015 / Disetujui 22 Juni 2015
}

\begin{abstract}
The objective of this research was to evaluate some vegetative and generative characters of the new IPB ornamental pepper lines. The experiment was conducted at IPB, Leuwikopo, Dramaga, Bogor in January to July 2014. The ornamental pepper lines Seroja, Ungaran, and cultivars Explosive, Numex, and Bara were evaluated. The design used was a completely randomized block design with four replications. There were significant differences for all quantitative characters among the observed new lines of ornamental pepper. Ungara had higher plant height, stem diameter, weight per fruit, fruit diameter, and flesh thickness than control. Seroja had earlier flowering time and harvest time than control. The qualitative characters were not significantly different among Seroja, Ungara, and control. Shortened internode and color change during ripening could be used to identity the observed newlines.
\end{abstract}

Keywords: ornamental pepper, generative, vegetative

\begin{abstract}
ABSTRAK
Penelitian bertujuan untuk mengevaluasi beberapa sifat vegetatif dan generatif dari galur cabai hias baru IPB. Penelitian dilaksanakan di Kebun Percobaan Leuwikopo, Dramaga, Bogor pada bulan Januari hingga Juli 2014. Bahan tanam yang digunakan adalah dua galur cabai hias IPB yaitu Seroja dan Ungara serta tiga varietas pembanding yaitu Explosive, Numex, dan Bara. Penelitian menggunakan Rancangan Kelompok Lengkap Teracak (RKLT) dengan 4 ulangan. Hasil penelitian menunjukkan galur-galur yang diuji memiliki perbedaan pada semua karakter kuantitatif yang diuji. Galur Ungara memiliki keunggulan pada karakter tinggi tanaman, diameter batang, bobot per buah, diameter buah, dan ketebalan kulit buah. Galur Seroja memiliki keunggulan pada karakter umur berbunga dan umur panen buah. Karakter-karakter kualitatif antara galur-galur yang diuji tidak menunjukkan banyak perbedaan dengan pembandingnya. Karakter kualitatif yang dapat mencirikan masing-masing galur dapat dilihat dari karakter pemendekan ruas dan perubahan warna buah.
\end{abstract}

Kata kunci: cabai hias, generatif, vegetatif

\section{PENDAHULUAN}

Cabai (Capsicum annuum L.) banyak dimanfaatkan masyarakat sebagai sayuran untuk konsumsi dan pelengkap masakan. Menurut Djarwaningsih (2005), tanaman Capsicum sebagai tanaman hias yang menarik untuk dibudidayakan. Menurut Setiadi (2002), cabai dalam pot memiliki nilai komersial sebagai tanaman hias. Tanaman cabai merupakan salah satu tanaman hias buah yang biasa ditanam dalam pot dan berfungsi baik sebagai tanaman hias dalam ruang dan di luar ruangan. Sementara itu menurut Hessayon (1993), segi estetika yang dapat dinikmati dari tanaman cabai hias adalah daun, bunga, serta buahnya.

Jenis cabai hias yang ada saat ini merupakan hasil seleksi, introduksi, maupun hibridisasi. Genotipe-genotipe baru yang

\footnotetext{
${ }^{1}$ Departemen Agronomi dan Hortikultura, Fakultas Pertanian, Institut Pertanian Bogor

(Bogor Agricultural University), J1. Meranti, Kampus IPB Darmaga, Bogor 16680, Indonesia

Telp.\&Faks.62-251-8629353. *Email korespondensi: dsukma70@yahoo.com
} 
terbentuk melalui proses evaluasi dan deskripsi calon varietas. Kegiatan evaluasi dan deskripsi dilakukan untuk mengetahui ciri-ciri keragaan genotipe-genotipe baru meliputi sifat vegetatif, sifat generatif, potensi produksi, dan ketahanan genotipe tersebut terhadap hama dan penyakit serta kondisi lingkungan tumbuh. Menurut Allard (1999), evaluasi dilakukan untuk mengetahui manfaat dan sifat-sifat dari galur baru tersebut. Dari kegiatan evaluasi tersebut dapat diketahui galur yang dapat dijadikan varietas budi daya (langsung disebarkan kepada petani), perlu seleksi lagi, dan galur yang dijadikan tetua dalam proses hibridisasi selanjutnya.

Cabai hias memiliki potensi untuk dikembangkan menjadi tanaman hias baru di masyarakat. Penelitian ini dilaksanakan untuk mengumpulkan dan mengevaluasi keragaan dari beberapa genotipe cabai hias. Penelitian ini bertujuan untuk mengevaluasi beberapa sifat vegetatif dan generatif galur cabai hias. Penelitian Syukur et al. (2010) pada tanaman cabai untuk pendugaan ragam, heritabilitas, dan korelasi untuk menentukan kriteria seleksi cabai menunjukkan bahwa karakter yang dijadikan kriteria seleksi adalah jumlah buah per tanaman, bobot buah, diameter pangkal, dan diameter tengah buah.

\section{METODE PENELITIAN}

Penelitian dilaksanakan di Kebun Percobaan Leuwikopo, Institut Pertanian Bogor, Dramaga, Bogor bulan Januari hingga Juli 2014. Persemaian benih dilaksanakan di Laboratorium Pemuliaan Tanaman, Departemen Agronomi dan Hortikultura, Fakultas Pertanian, Institut Pertanian Bogor. Bahan tanaman yang digunakan adalah dua galur cabai hias IPB (Seroja dan Ungara) serta tiga varietas pembanding (Explosive, Numex, dan Bara). Media yang digunakan adalah media tanam campuran, pupuk NPK dan pupuk daun. Alat yang digunakan antara lain tray semai, pot (diameter $20 \mathrm{~cm}$ ), penggaris (meteran), jangka sorong, kamera, alat tulis, dan alat-alat pertanian.

Penyemaian benih dilakukan di tray semai dengan campuran media tanam Supergrow dan Bioposka dengan perbandingan 1:1. Pengisian media tanam ke dalam pot dilakukan satu minggu sebelum pindah tanam yang berisi campuran media tanam Super-grow, Bioposka dengan perbandingan 1:1. Pindah tanam dilakukan setelah bibit berumur \pm 28 hari. Pada umur \pm 4 minggu setelah tanam (MST) dilakukan penambahan kompos dan media tanam dengan perbandingan 1:1. Pemupukan dilakukan dengan menggunakan larutan NPK (16:16:16) $\quad 10 \quad \mathrm{~g} \mathrm{~L} \mathrm{~L}^{-1}$ sebanyak $250 \mathrm{~mL}$ pertanaman. Aplikasi Furadan dilakukan pada saat penanaman. Pengendalian gulma dilakukan secara manual, sementara pengendalian hama dan penyakit dilakukan satu minggu sekali.

Peubah yang diamati meliputi:

a. Tinggi tanaman, diukur dari permukaan tanah sampai pucuk tanaman tertinggi pada panen kedua.

b. Tinggi dikotomus, diukur dari permukaan tanah sampai percabangan pertama pada panen kedua.

c. Karakter batang:

1. Bentuk batang, diamati pada saat panen kedua.

2. Warna batang: hijau tua, hijau, hijau kekuningan, dan lainnya yang diamati pada saat panen kedua.

3. Diameter batang, diukur pada saat panen kedua.

4. Pemendekan batang: tidak ada, satu sampai tiga, dan lebih dari tiga.

d. Habitus tanaman: menyamping, kompak dan tegak, diamati ketika $50 \%$ populasi tanaman telah mempunyai buah masak.

e. Karakter daun:

1. Bentuk daun: bulat telur, bulat, belah ketupat, ginjal, silindris berlubang, lainnya yang diamati pada panen kedua.

2. Warna daun: hijau tua, hijau muda, hijau kekuningan.

3. Ukuran daun: panjang ... $\mathrm{cm} \times$ lebar ... $\mathrm{cm}$, diukur rata-rata dari 10 daun yang telah berukuran maksimal pada percabangan utama pada panen kedua.

4. Permukaan daun, diamati pada setiap genotipe.

5. Tepi daun: rata, bergerigi, berombak, lainnya.

6. Ujung daun: runcing, meruncing, tumpul, membelah, membuka, lainnya.

f. Karakter bunga dan buah:

1. Waktu munculnya bunga, jumlah hari setelah tanam sampai $50 \%$ populasi mempunyai bunga mekar.

2. Warna mahkota bunga: putih, kuning terang, kuning, ungu dengan dasar 
putih, putih dengan dasar ungu, putih dengan pinggiran ungu, ungu, dan lainnya. Diamati setelah bunga pertama membuka sempurna.

3. Kedudukan bunga: pendant, intermediate, erect

4. Umur panen buah, jumlah hari setelah tanam sampai $50 \%$ populasi mempunyai buah masak.

5. Bobot buah (g) ditimbang bobot 10 buah cabai masak yang diambil dari panen kedua.

6. Panjang buah $(\mathrm{cm})$ diukur dari pangkal sampai ujung buah pada 10 buah yang sama dengan pengamatan bobot buah.

7. Panjang tangkai buah $(\mathrm{cm})$ diukur dari pangkal sampai ujung tangkai buah pada 10 buah yang sama dengan pe-ngamatan bobot buah.

8. Diameter buah $(\mathrm{mm})$ diukur pada tiga bagian buah yaitu: pangkal, tengah, dan ujung pada 10 buah yang sama dengan pengamatan bobot buah.

9. Ketebalan kulit buah $(\mathrm{mm})$, diukur dari rata-rata 10 buah masak pada panen kedua. Pengukuran dilakukan dengan menggunakan jangka sorong digital.

10.Bentuk buah: elongate, almost round, triangular, campanulate, blocky, lainnya yang diamati pada saat panen kedua.

11.Bentuk pangkal buah: acute, obtuse, truncate, cordate, lobate yang diamati pada saat panen kedua.

12.Penampang melintang buah: pointed, blunt, sunken, sunken \& pointed, lainnya yang diamati pada saat panen kedua.

13.Perubahan warna buah, diamati saat buah muda hingga buah tua.

Rancangan percobaan yang digunakan adalah Rancangan Kelompok Lengkap Teracak (RKLT) satu faktor yaitu galur cabai hias dengan empat ulangan. Data diolah menggunakan uji $\mathrm{F}$ pada selang kepercayaan $95 \%(\alpha$ $=5 \%$ ), yang kemudian akan dilanjutkan dengan uji lanjut menggunakan uji DMRT apabila terdapat perbedaan yang nyata pada taraf $5 \%$.

\section{HASIL DAN PEMBAHASAN}

Selama masa persemaian, daya berkecambah untuk Seroja, Ungara, dan Bara adalah $89.51 \%$, namun daya berkecambah untuk Explosive dan Numex cukup rendah dengan rata-rata daya berkecambah sebesar $36.83 \%$. Penanaman bibit ke pot atau transplanting dilakukan dua kali. Hal ini dilakukan karena pertumbuhan bibit tanaman yang tidak seragam di persemaian. Ketidakseragaman pertumbuhan bibit tanaman ini terjadi kemungkinan karena bibit mengalami kondisi stress di persemaian. Hama dominan yang menyerang tanaman cabai di lapangan adalah thrips (Thrips parvisipinus) dan kutu daun. Hama ini menyerang bagian daun khususnya di permukaan bawah daun tanaman yang kemudian menyebabkan daun tanaman menjadi keriting.

Penyakit yang paling dominan menyerang tanaman cabai di lapangan dan menyebabkan perubahan keragaan tanaman cabai serta penurunan jumlah produksi adalah Antraknosa dan layu Fusarium. Penyakit Antraknosa disebabkan oleh Colletotrichum acutatum yang menyebabkan bercak konsentrik berwarna hitam pada buah sehingga buah menjadi busuk basah. Penyakit ini awalnya menyerang tanaman cabai hias Numex pada ulangan 2 yang kemudian menyebar ke seluruh tanaman pada tiap ulangan. Sementara itu, penyakit layu Fusarium (Fusarium oxysporum Schlecth) menyerang tanaman cabai dengan gejala awal tanaman menjadi layu yang dilanjutkan dengan gugurnya daun-daun yang telah mengering sebelumnya. Curah hujan dan kelembaban relatif yang tinggi selama penelitian berlangsung diduga merupakan salah satu penyebab meningkatnya serangan penyakit terutama yang disebabkan oleh cendawan. Berdasarkan data dari Stasiun Meteorologi dan Geofisika, Bogor (2014), pada bulan Januari sampai bulan Juli 2014, curah hujan rata-rata $524 \mathrm{~mm}$ bulan $^{-1}$, suhu $24.6-26.5{ }^{0} \mathrm{C}$, dan kelembaban $87.4 \%$.

Secara umum, pengendalian hama dan penyakit yang menyerang tanaman cabai dapat dilakukan dengan menggunakan pestisida sesuai dosis yang dianjurkan dan penyemprotan insektisida dan fungisida setiap minggunya baik pada fase vegetatif maupun generatif tanaman

\section{Keragaan Tanaman}

Pengujian keragaan tanaman menunjukkan adanya perbedaan antara galur-galur yang diuji pada seluruh karakter kuantitatif yang 
diamati, yaitu karakter tinggi tanaman, tinggi dikotomus, diameter batang, lebar tajuk, lebar daun, panjang daun, umur berbunga, umur panen buah, bobot buah per tanaman, bobot buah, jumlah buah per tanaman, diameter pangkal buah, diameter tengah buah, diameter ujung buah, panjang buah, panjang tangkai buah, dan ketebalan kulit buah. Koefisien keragaman (kk) pada seluruh karakter kuantitatif yang diamati berkisar antara 5.18-18.93\% (Tabel 1).

\section{Evaluasi Karakter Kualitatif Karakter Vegetatif}

Karakter-karakter vegetatif yang diuji antara lain bentuk daun, tepi daun, ujung daun, permukaan daun, warna daun, bentuk batang, warna batang, dan habitus tanaman tidak menunjukkan banyak perbedaan, bahkan pada karakter ujung daun, permukaan daun, dan bentuk batang pada seluruh galur yang diuji dan pembanding tidak menunjukkan perbedaan.

Bentuk daun pada kedua galur yang diuji dan ketiga pembanding berbentuk lanset dan oval. Karakter tepi daun yang dominan muncul baik pada galur yang diuji maupun pembanding adalah berombak dan rata, sementara warna daun yang terlihat adalah hijau dan hijau keunguan. Perbedaan karakter antara galur yang diuji dan pembanding tidak terlihat pada karakter ujung daun dan permukaan daun (Tabel 2).

Pengamatan karakter bentuk batang tidak menunjukkan perbedaan. Semua galur yang diuji mempunyai bentuk batang yang sama dengan pembanding yaitu silindris. Warna batang serta habitus tanaman yang diuji menunjukkan perbedaan dengan pembanding. Warna batang dari sebagian besar pembanding berwarna hijau sedangkan warna batang dari salah satu galur yang diuji berwarna ungu. Pemendekan ruas hanya terdapat pada galur Seroja dan satu pembandingnya yaitu Explosive. Karakter habitus tanaman yang dominan muncul baik pada galur yang diuji maupun pembanding adalah kompak dan tegak (Tabel 3).

Tabel 1. Rekapitulasi F-Hitung, peluang, dan koefisiensi keragaman

\begin{tabular}{clrrr}
\hline No. & \multicolumn{1}{c}{ Karakter } & F Hitung & Peluang & Koefisien Keragaman $(\%)$ \\
\hline 1 & Tinggi tanaman $(\mathrm{cm})$ & $253.02^{* *}$ & $<.0001$ & 5.85 \\
2 & Tinggi dikotomus $(\mathrm{cm})$ & $132.55^{* *}$ & $<.0001$ & 10.81 \\
3 & Diameter batang $(\mathrm{mm})$ & $51.38^{* *}$ & $<.0001$ & 7.24 \\
4 & Lebar tajuk $(\mathrm{cm})$ & $137.18^{* *}$ & $<.0001$ & 7.58 \\
5 & Lebar daun $(\mathrm{cm})$ & $23.14^{* *}$ & $<.0001$ & 5.18 \\
6 & Panjang daun $(\mathrm{cm})$ & $18.29^{* *}$ & $<.0001$ & 8.06 \\
7 & Umur berbunga (HST) & $22.55^{* *}$ & $<.0001$ & 11.39 \\
8 & Umur panen buah (HST) & $10.08^{* *}$ & 0.0008 & 5.87 \\
9 & Bobot buah per tanaman $(\mathrm{g})$ & $56.90^{* *}$ & $<.0001$ & 18.93 \\
10 & Bobot buah $(\mathrm{g})$ & $57.47^{* *}$ & $<.0001$ & 13.03 \\
11 & Jumlah buah per tanaman & $112.19^{* *}$ & $<.0001$ & 18.07 \\
12 & Diameter pangkal buah $(\mathrm{mm})$ & $93.06^{* *}$ & $<.0001$ & 6.45 \\
13 & Diameter tengah buah $(\mathrm{mm})$ & $76.39^{* *}$ & $<.0001$ & 7.32 \\
14 & Diameter ujung buah $(\mathrm{mm})$ & $78.74^{* *}$ & $<.0001$ & 9.68 \\
15 & Panjang buah $(\mathrm{cm})$ & $6.13^{* *}$ & 0.0063 & 10.62 \\
16 & Panjang tangkai buah $(\mathrm{cm})$ & $34.83^{* *}$ & $<.0001$ & 5.48 \\
17 & Ketebalan kulit buah $(\mathrm{mm})$ & $26.83^{* *}$ & $<.0001$ & 11.49 \\
\hline
\end{tabular}

Keterangan: $* *=$ berpengaruh sangat nyata pada uji $\mathrm{F}$ taraf $\alpha=0.01$

Tabel 2. Bentuk daun, tepi daun, ujung daun, permukaan daun, dan warna daun

\begin{tabular}{lccccc}
\hline Genotipe & Bentuk Daun & Tepi Daun & Ujung Daun & Permukaan Daun & Warna Daun \\
\hline Seroja & Lanset & Berombak & Meruncing & Halus & Hijau \\
Ungara & Oval & Rata & Meruncing & Halus & Hijau keunguan \\
Explosive & Lanset & Rata & Meruncing & Halus & Hijau keunguan \\
Numex & Lanset & Berombak & Meruncing & Halus & Hijau \\
Bara & Oval & Rata & Meruncing & Halus & Hijau \\
\hline
\end{tabular}


Tabel 3. Bentuk batang, warna batang, dan habitus tanaman

\begin{tabular}{lcccc}
\hline \multicolumn{1}{c}{ Genotipe } & Bentuk Batang & Pemendekan Ruas & Warna Batang & Habitus Tanaman \\
\hline Seroja & Silindris & Ada & Hijau & Kompak \\
Ungara & Silindris & Tidak ada & Ungu & Tegak \\
Explosive & Silindris & Ada & Ungu & Kompak \\
Numex & Silindris & Tidak ada & Hijau & Kompak \\
Bara & Silindris & Tidak ada & Hijau & Tegak \\
\hline
\end{tabular}

\section{Karakter Generatif}

Karakter posisi bunga pada galur yang diuji tidak berbeda dengan semua pembanding. Keseluruhan galur yang diuji dan pembanding memiliki posisi bunga yang tegak. Untuk karakter warna mahkota bunga, galur Seroja memiliki warna mahkota putih, sementara galur Ungara memiliki warna mahkota bunga ungu. Karakter warna mahkota bunga Seroja memiliki perbedaan dengan pembanding Explosive yang memiliki warna mahkota ungu, sementara warna mahkota bunga Ungara memiliki perbedaan dengan warna mahkota pada pembanding Numex dan Bara (Tabel 4).

Pengamatan karakter kualitatif buah meliputi bentuk buah, bentuk pangkal buah, penampang melintang buah, dan perubahan warna buah. Karakter bentuk buah pada dua galur yang diuji hanya memiliki perbedaan dengan salah satu pembanding yaitu Bara. Galur Seroja dan Ungara memiliki bentuk buah triangular sementara pembanding Bara memiliki bentuk buah memanjang. Bentuk pangkal buah pada galur yang diuji juga memiliki perbedaan dari pembanding. Kedua galur yang diuji memiliki bentuk pangkal buah yang rompang. Bentuk ini berbeda dengan bentuk pangkal buah dua dari tiga pembanding yaitu Numex dan Bara yang masing-masing berbentuk jantung dan tumpul. Perbedaan juga terlihat pada karakter perubahan warna buah. Masing-masing galur yang diuji dan pembanding memiliki perubahan warna buah muda ke buah matang yang berbeda, sementara itu keseluruhan galur yang diuji serta pembandingnya tidak memiliki perbedaan pada karakter penampang melintang buah (Tabel 5).

Tabel 4. Posisi bunga dan warna mahkota bunga

\begin{tabular}{lcc}
\hline Genotipe & $\begin{array}{c}\text { Posisi } \\
\text { Bunga }\end{array}$ & $\begin{array}{c}\text { Warna } \\
\text { Mahkota } \\
\text { Bunga }\end{array}$ \\
\hline Seroja & Tegak & Putih \\
Ungara & Tegak & Ungu \\
Explosive & Tegak & Ungu \\
Numex & Tegak & Putih \\
Bara & Tegak & Putih \\
\hline
\end{tabular}

Tabel 5. Bentuk buah, bentuk pangkal buah, penampang melintang buah, dan perubahan warna buah

\begin{tabular}{|c|c|c|c|c|}
\hline Genotipe & Bentuk Buah & $\begin{array}{l}\text { Bentuk Pangkal } \\
\text { Buah }\end{array}$ & $\begin{array}{c}\text { Penampang } \\
\text { Melintang Buah }\end{array}$ & Perubahan Warna Buah \\
\hline Seroja & Triangular & Rompang & Sedikit berombak & $\begin{array}{l}\text { hijau kekuningan - hijau } \\
\text { keunguan - ungu - oranye } \\
\text { keunguan - oranye - merah }\end{array}$ \\
\hline Ungara & Triangular & Rompang & Sedikit berombak & $\begin{array}{l}\text { ungu kehitaman - hijau - } \\
\text { merah kehitaman - merah }\end{array}$ \\
\hline Explosive & Triangular & Rompang & Sedikit berombak & $\begin{array}{l}\text { ungu - ungu semburat } \\
\text { oranye - oranye - merah }\end{array}$ \\
\hline Numex & Triangular & Bentuk jantung & Sedikit berombak & $\begin{array}{l}\text { hijau kekuningan - ungu - } \\
\text { oranye - merah }\end{array}$ \\
\hline Bara & Memanjang & Tumpul & Sedikit berombak & hijau - oranye - merah \\
\hline
\end{tabular}




\section{Evaluasi Karakter Kuantitatif Tinggi Tanaman, Tinggi Dikotomus, dan Diameter Batang}

Tinggi tanaman galur cabai hias yang diuji berkisar antara 20.19-48.90 cm. Galur Ungara memiliki tinggi tanaman tertinggi dibandingkan dengan semua pembanding, sementara Seroja memiliki tinggi tanaman yang lebih rendah dibandingkan dengan Bara namun masih setara dengan tinggi tanaman dari Explosive dan Numex. Galur Ungara juga memiliki diameter batang terbesar di antara pembanding-pembandingnya yaitu sebesar 9.89 $\mathrm{mm}$, sementara diameter batang dari galur Seroja sebanding dengan besar diameter pada Explosive (Tabel 6).

Tinggi dikotomus dari kedua galur yang diuji ini tidak lebih tinggi dari pembandingnya yaitu Bara, namun galur Ungara memiliki tinggi dikotomus yang lebih tinggi dibandingkan dengan Explosive dan Numex, sementara tinggi dikotomus Seroja sebanding dengan Numex (Tabel 6).

Berdasarkan hasil pengamatan, karakter tinggi tanaman, tinggi dikotomus, dan diameter batang menunjukkan hubungan yang berbanding lurus, di mana semakin tinggi tanaman maka tinggi dikotomus dan diameter batang juga akan semakin besar.

\section{Lebar Tajuk, Lebar Daun, dan Panjang Daun}

Galur Seroja memiliki lebar tajuk terendah di antara pembanding-pembandingnya, sementara lebar tajuk Ungara tidak lebih lebar dari tajuk Bara namun lebih lebar dari Explosive dan Numex. Tanaman dengan tajuk yang lebar diharapkan dapat menghasilkan jumlah cabang yang banyak sehingga buah yang dihasilkan pun akan semakin banyak. Karakter lebar daun dan panjang daun pada galur yang diuji menunjukkan hasil yang hampir sama, lebar dan panjang daun dari kedua galur yang diuji tidak lebih baik dari Bara. Lebar daun pada kedua galur yang diuji setara dengan Numex dan lebih lebar bila dibandingkan dengan Explosive (Tabel 7).

\section{Umur Berbunga, Umur Panen Buah, Bobot Buah Tanaman ${ }^{-1}$, Bobot Buah $^{-1}$, dan Jumlah Buah Tanaman ${ }^{-1}$}

Umur berbunga yang lebih lama dibandingkan pembanding ditunjukkan oleh galur Ungara dengan rata-rata waktu berbunga selama 35.5 hari setelah tanam, sementara waktu berbunga galur Seroja lebih cepat bila dibandingkan dengan Numex dan Bara. Umur panen buah diukur berdasarkan jumlah hari setelah tanam sampai 50\% tanaman dalam petak percobaan telah mengalami pemasakan buah. Umur panen buah galur Ungara adalah yang terlama dibandingkan dengan semua pembanding, sementara galur Seroja memiliki umur panen buah tercepat di antara semua pembanding (Tabel 8).

Tabel 6. Nilai tengah karakter tinggi tanaman, tinggi dikotomus, dan diameter batang yang diuji pada setiap galur

\begin{tabular}{lccc}
\hline \multicolumn{1}{c}{ Genotipe } & Tinggi Tanaman $(\mathrm{cm})$ & Tinggi Dikotomus $(\mathrm{cm})$ & Diameter Batang $(\mathrm{mm})$ \\
\hline Seroja & $20.19^{\mathrm{cd}}$ & $6.42^{\mathrm{c}}$ & $5.31^{\mathrm{c}}$ \\
Ungara & $48.90^{\mathrm{a}}$ & $14.10^{\mathrm{b}}$ & $9.89^{\mathrm{a}}$ \\
Explosive & $19.44^{\mathrm{d}}$ & $4.68^{\mathrm{d}}$ & $5.58^{\mathrm{c}}$ \\
Numex & $22.57^{\mathrm{c}}$ & $5.08^{\mathrm{cd}}$ & $7.79^{\mathrm{b}}$ \\
Bara & $45.44^{\mathrm{b}}$ & $17.93^{\mathrm{a}}$ & $7.19^{\mathrm{b}}$ \\
\hline
\end{tabular}

Keterangan: Angka yang diikuti huruf yang sama pada kolom yang sama menunjukkan hasil yang tidak berbeda nyata menurut uji DMRT

Tabel 7. Nilai tengah karakter lebar tajuk, lebar daun, dan panjang daun yang diuji pada setiap galur

\begin{tabular}{lccc}
\hline \multicolumn{1}{c}{ Genotipe } & Lebar Tajuk $(\mathrm{cm})$ & Lebar Daun $(\mathrm{cm})$ & Panjang Daun $(\mathrm{cm})$ \\
\hline Seroja & $22.71^{\mathrm{e}}$ & $2.27^{\mathrm{b}}$ & $6.18^{\mathrm{b}}$ \\
Ungara & $56.43^{\mathrm{b}}$ & $2.19^{\mathrm{b}}$ & $5.15^{\mathrm{cd}}$ \\
Explosive & $29.42^{\mathrm{d}}$ & $1.78^{\mathrm{c}}$ & $4.49^{\mathrm{d}}$ \\
Numex & $35.71^{\mathrm{c}}$ & $2.28^{\mathrm{b}}$ & $5.35^{\mathrm{c}}$ \\
Bara & $67.14^{\mathrm{a}}$ & $2.54^{\mathrm{a}}$ & $6.99^{\mathrm{a}}$ \\
\hline Keterangan: & Angka yang diikuti huruf yang sama pada kolom yang sama menunjukkan hasil yang tidak berbeda
\end{tabular}


Tabel 8. Nilai tengah karakter umur berbunga, umur panen buah, bobot buah per tanaman, bobot per buah, dan jumlah buah per tanaman

\begin{tabular}{lccccc}
\hline Genotipe & $\begin{array}{c}\text { Umur Berbunga } \\
(\text { HST) }\end{array}$ & $\begin{array}{c}\text { Umur Panen Buah } \\
(\text { HST })\end{array}$ & $\begin{array}{c}\text { Bobot Buah } \\
\text { Tanaman }^{-1}(\mathrm{~g})\end{array}$ & $\begin{array}{c}\text { Bobot Buah } \\
(\mathrm{g})\end{array}$ & $\begin{array}{c}\text { Jumlah Buah } \\
\text { Tanaman }^{-1}\end{array}$ \\
\hline Seroja & $18.3^{\mathrm{d}}$ & $60.5^{\mathrm{c}}$ & $36.36^{\mathrm{d}}$ & $1.65^{\mathrm{c}}$ & $23.5^{\mathrm{c}}$ \\
Ungara & $35.5^{\mathrm{a}}$ & $77.5^{\mathrm{a}}$ & $110.40^{\mathrm{b}}$ & $2.53^{\mathrm{a}}$ & $44.5^{\mathrm{b}}$ \\
Explosive & $20.8^{\mathrm{cd}}$ & $70.3^{\mathrm{b}}$ & $20.51^{\mathrm{d}}$ & $0.63^{\mathrm{e}}$ & $32.8^{\mathrm{bc}}$ \\
Numex & $29.5^{\mathrm{b}}$ & $69.8^{\mathrm{b}}$ & $58.34^{\mathrm{c}}$ & $2.16^{\mathrm{b}}$ & $28.5^{\mathrm{bc}}$ \\
Bara & $24.3^{\mathrm{c}}$ & $64.8^{\mathrm{bc}}$ & $148.77^{\mathrm{a}}$ & $0.99^{\mathrm{d}}$ & $151.0^{\mathrm{a}}$ \\
\hline
\end{tabular}

Karakter bobot buah per tanaman, bobot buah $^{-1}$, dan jumlah buah tanaman ${ }^{-1}$ merupakan karakter-karakter yang saling berhubungan, di mana bobot buah tanaman ${ }^{-1}$ dan bobot buah dapat menentukan jumlah buah yang dapat dihasilkan dari satu tanaman cabai. Karakter umur berbunga juga berbanding lurus dengan bobot buah, Penelitian Setyaningsih (1994), semakin lama tanaman memasuki fase generatif berarti semakin banyak bagian vegetatif tanaman sehingga tanaman mempunyai kemampuan menghasilkan fotosintat yang banyak untuk pembentukan buah.

\section{Diameter Pangkal Buah, Diamater Tengah Buah, dan Diamater Ujung Buah}

Karakter diameter buah yang diukur meliputi tiga bagian buah yaitu pangkal, tengah, dan ujung buah. Diameter pangkal buah, tengah buah, dan ujung buah dari galur yang diuji masing-masing berkisar antara 11.24-14.54 $\mathrm{mm}, 9.44-13.24 \mathrm{~mm}$, serta $4.21-7.12 \mathrm{~mm}$.
Galur Ungara memiliki diameter pangkal, tengah, dan ujung buah yang lebih lebar dibandingkan dengan semua pembanding, sementara galur Seroja memiliki diameter pangkal, tengah, dan ujung buah lebih lebar bila dibandingkan dengan pembanding Explosive dan Bara (Tabel 9). Karakter diameter buah ini dapat digunakan untuk membantu menentukan bentuk buah cabai.

\section{Panjang Buah, Panjang Tangkai Buah, dan Ketebalan Kulit Buah}

Berdasarkan hasil pengamatan, rata-rata panjang buah dari galur yang diuji berkisar antara 3.01-3.08 cm. Keseluruhan galur yang diuji memiliki panjang buah yang setara dengan Numex namun lebih panjang bila dibandingkan dengan Explosive. Hasil pengamatan pada karakter panjang tangkai buah menunjukkan hasil yang sama dengan pengamatan karakter panjang buah (Tabel 10).

Tabel 9. Nilai tengah karakter diameter pangkal buah, diameter tengah buah, dan diameter ujung buah yang diuji pada setiap galur

\begin{tabular}{lcrc}
\hline \multicolumn{1}{c}{ Genotipe } & $\begin{array}{c}\text { Diameter Pangkal Buah } \\
(\mathrm{mm})\end{array}$ & $\begin{array}{c}\text { Diameter Tengah Buah } \\
(\mathrm{mm})\end{array}$ & $\begin{array}{c}\text { Diameter Ujung Buah } \\
(\mathrm{mm})\end{array}$ \\
\hline Seroja & $11.24^{\mathrm{b}}$ & $9.44^{\mathrm{c}}$ & $4.21^{\mathrm{b}}$ \\
Ungara & $14.54^{\mathrm{a}}$ & $13.24^{\mathrm{a}}$ & $7.12^{\mathrm{a}}$ \\
Explosive & $8.12^{\mathrm{c}}$ & $6.98^{\mathrm{d}}$ & $3.32^{\mathrm{c}}$ \\
Numex & $14.81^{\mathrm{a}}$ & $11.93^{\mathrm{b}}$ & $6.64^{\mathrm{a}}$ \\
Bara & $7.31^{\mathrm{c}}$ & $6.16^{\mathrm{d}}$ & $2.47^{\mathrm{d}}$ \\
\hline
\end{tabular}

Keterangan: Angka yang diikuti huruf yang sama pada kolom yang sama menunjukkan hasil yang tidak berbeda nyata menurut uji DMRT

Tabel 10. Nilai tengah karakter panjang buah, panjang tangkai buah, dan ketebalan kulit buah yang diuji pada setiap galur

\begin{tabular}{lccc}
\hline \multicolumn{1}{c}{ Genotipe } & Panjang Buah $(\mathrm{cm})$ & Panjang Tangkai Buah $(\mathrm{cm})$ & Ketebalan Kulit Buah $(\mathrm{mm})$ \\
\hline Seroja & $3.08^{\mathrm{b}}$ & $2.62^{\mathrm{bc}}$ & $1.23^{\mathrm{b}}$ \\
Ungara & $3.01^{\mathrm{b}}$ & $2.73^{\mathrm{b}}$ & $1.66^{\mathrm{a}}$ \\
Explosive & $2.50^{\mathrm{c}}$ & $2.45^{\mathrm{c}}$ & $1.14^{\mathrm{b}}$ \\
Numex & $3.18^{\mathrm{ab}}$ & $2.44^{\mathrm{c}}$ & $1.45^{\mathrm{a}}$ \\
Bara & $3.64^{\mathrm{a}}$ & $3.52^{\mathrm{a}}$ & $0.68^{\mathrm{c}}$ \\
\hline
\end{tabular}

Keterangan: Angka yang diikuti huruf yang sama pada kolom yang sama menunjukkan hasil yang tidak berbeda nyata menurut uji DMRT 
Ketebalan kulit buah galur cabai yang diuji berkisar antara 1.23-1.66 mm. Galur Ungara memiliki tebal kulit terbesar di antara pembanding Explosive dan Bara, namun setara dengan tebal kulit buah Numex. Tebal kulit buah galur Seroja setara dengan tebal kulit buah Explosive, namun lebih tebal bila dibandingkan dengan tebal kulit buah Bara (Tabel 10). Karakter panjang buah dan panjang tangkai buah memiliki hubungan yang berbanding lurus, di mana galur dengan panjang buah terpanjang akan memiliki panjang tangkai buah terpanjang pula. Sementara itu, ketebalan kulit buah tidak bergantung pada besarnya panjang buah dan panjang tangkai buah.

\section{KESIMPULAN}

Galur-galur yang memiliki perbedaan pada semua karakter kuantitatif yang diamati, meliputi karakter tinggi tanaman, tinggi dikotomus, diameter batang, lebar tajuk, lebar daun, panjang daun, umur berbunga, umur panen buah, bobot buah per tanaman, bobot per buah, jumlah buah per tanaman, diameter buah, panjang buah, panjang tangkai buah, dan ketebalan kulit buah. Galur Ungara memiliki keunggulan pada karakter tinggi tanaman, diameter batang, bobot per buah, diameter buah, dan ketebalan kulit buah. Galur Seroja memiliki keunggulan pada karakter umur berbunga dan umur panen buah.

Karakter kualitatif yang diuji pada galur cabai hias menunjukkan sedikit perbedaan dengan pembandingnya. Perbedaan yang paling menonjol dari karakter-karakter kualitatif yang diuji adalah karakter pemendekan ruas dan perubahan warna buah. Galur Seroja mengalami pemendekan ruas dengan perubahan warna buah ungu muda saat muda kemudian menjadi merah saat tua, sementara galur Ungara tidak mengalami pemendekan ruas dengan perubahan warna buah dari ungu kehitaman menjadi merah.

\section{DAFTAR PUSTAKA}

Allard, R.W. 1999. Principle of Plant Breeding. 2nd ed. John Wiley \& Sons, Inc. New York (US).

Djarwaningsih, T. 2005. Capsicum spp. (Cabai): Asal, persebaran, dan nilai ekonomi. Biodiversitas. 6(4): 292-296.

Gomez, K.A, A.A. Gomez. 1995. Prosedur Statistika untuk Penelitian Pertanian. 2nd ed. Sjamsudin E, J.S. Baharsjah, penerjemah. UI Pr. Terjemahan dari: Stasistical Prosedures for Agricultural Research. Jakarta.

Hessayon, D.G. 1993. The House Plant Expert. Transworld Publisher Ltd. London (GB).

[IPGRI] International Plant Genetic Resources Institute. 1995. Descriptors for Capsicum (Capsicum spp.). International Plant Genetic Resources Institute. Roma (IT).

Setiadi. 2002. Bertanam Cabai. Penebar Swadaya. Jakarta.

Setyaningsih P. 1994. Evaluasi karakter hortikultura dan daya hasil lima belas galur cabai (Capsicum annuum L.) lokal dan introduksi. Skripsi. Institut Pertanian Bogor. Bogor.

Syukur, M., S. Sujiprihati, R. Yunianti, K. Nida. 2010. Pendugaan komponen ragam, heritabilitas, dan korelasi untuk menentukan kriteria seleksi cabai (Capsicum annиum L.) populasi F5. J. Hort. Indonesia. 1 (2) : 74-80 